\title{
Bioconversion and Bioeconomic of Wastewater from Red Tilapia Aquaculture on the Aquaponics System as Source of Nutrient in Green Mustard Growth
}

\author{
Latif. Sahubawa ${ }^{*}, B$. Triyatmo ${ }^{1}$ and E. Ambarwati ${ }^{2}$ \\ ${ }^{1}$ Departement of Fisheries, Faculty of Agriculture, Gadjah Mada University, Yogyakarta \\ ${ }^{2}$ Departement of Agriculture Cultivation, Faculty of Agriculture, Gadjah Mada University, \\ Yogyakarta, PO Box 55281, Indonesia.
}

\begin{abstract}
Fish farming activities produce large amounts of waste which is disposed to environment. It contains with ammonia and nitrite as toxic substances to aquatic biota. On the other hand, it also contains nitrate as macronutrient which is useful for vegetables. Aquaponics system provides multiple benefits, namely the production of fish and organic vegetables as by-products that potentially to be a source of income. The objectives of the research were to analyse physical-chemical quality of red tilapia aquaculture and cultivated vegetable in aquaponics system, fish farm wastewater discharge for vegetable cultivation, bioconversion of aquaculture wastewater for growing vegetable biomass, and the bioeconomic of the system. The physical-chemical quality from water body of the system were as followed $\mathrm{pH}=7.2-7.6$; Temperature $=27,4-28,0^{\circ} \mathrm{C} ; \mathrm{EC}=392.0-400.0$ $\mu \mathrm{s} / \mathrm{cm} ; \mathrm{TDS}=180.5-189.7 ; \mathrm{NO}_{3}=3.751-5.266 \mathrm{mg} . \mathrm{L}^{-1}$. The total biomass of green mustard in recirculating system was $92.50 \mathrm{~kg} /$ tray unit and in dripping system was $138 \mathrm{~kg} /$ tray unit. In one harvest period of red tilapia, the production of green mustard biomass was $1,152.5 \mathrm{~kg}$, with an economic value of IDR 8,643,750.00 and IDR 1,680,000.00 for the red tilapia biomass.
\end{abstract}

\section{Introduction}

Aquaponics system aquaculture is one of the concepts of integrated fish and vegetable cultivation with the aim of increasing added value from the use of wastewater as a source of nutrients for vegetable/fruit cultivation in an integrated and sustainable manner in the provision of high-quality organic food [1]. According to [2], aquaponic system cultivation on an intensive scale by providing high-quality feed, has a significant influence on fish biomass as well as the provision of nutrients (nitrates) that have potential to develop vegetable/fruit cultivation, while preventing fish deaths due to the decline in fish pond water quality.

Aquaculture wastewater is used as liquid organic fertilizer for the cultivation of vegetables/fruit of important economic value in an integrated manner as an alternative source of income for the fish farmer. Utilization of wastewater from fish farming for vegetable cultivation is one of smart solutions to reduce the water pollution to obtain maximum fish 
growth, organic vegetable production, to reduce waste and use of ground water and contribute to environmental pollution control [2]. In the era of modern technology, high quality of food should be produced massively and independently. Aquaponics is an appropriate technology for cultivating plants that are economical-productive and environmentally friendly by utilizing limited land and minimizing water use [3].

The advancement of science, technology and art in the field of bioconversion and bioeconomics, makes aquaculture wastewater maximally utilized as a source of nutrients in the cultivation of vegetables and fruit (horticulture). The application of aquaponic systems theoretically, practically and economically is very beneficial because the land used is relatively small, multipurpose (fish, various vegetables and fruits), saving water, preventing the use of antibiotics and free of antibiotic residues. The technical-practical advantage is that it is not necessary to work on land, free of fertilizers and pesticides, without irrigation and use nutrient-rich wastewater from fish farming. According to [4] and [5] some types of potential fish for aquaponics are tilapia, carp, pomfret, pangasius, catfish, while the vegetables are spinach, mustard greens, kale, lettuce, celery, tomatoes, chili, eggplant and others [3], [6].

It is expected that with the development of aquaponics system, community groups of fish and vegetable farmers can be facilitated and empowered in optimally utilizing land resources, fisheries and environmental resources for family economic improvement. The groups accompanied by university researchers are expected to be able to optimize aquaponic system independently so that they can produce fish and organic vegetables to meet local and national market needs, as well as to increase family income and welfare in a sustainable manner. The main objectives of the research were (a) to analyse physical-chemical quality of cultured red tilapia and cultivated vegetable in aquaponics system, (b) to analyse fish farm wastewater discharge for vegetable cultivation, (c) to analyse bioconversion of aquaculture wastes water for growing vegetable biomass, (d) analysis bioeconomic of the system.

\section{Materials and Method}

\subsection{Materials and equipments}

The materials and equipments used were fish tank (fiberglass) for fish culture, aquaponic tray with recirculating system (PVC pipe) and aquaponic tray with dripping system (polybags and plastic pots) for vegetable cultivation. The number of fish tanks used were three units, with the shape and size of each: (a) two rectangular tanks (length $=2.5 \mathrm{~m}$, width $=1.5 \mathrm{~m}$, height $=1.0 \mathrm{~m}$ ) with a water volume of approximately $2.6 \mathrm{~m}^{3}$ and (b) one cylindrical tank (length $=1.5 \mathrm{~m}$, width $=1.5 \mathrm{~m}$, height $=1.0 \mathrm{~m}$ ) with a water volume of approximately $1.5 \mathrm{~m}^{3}$ (Figure 1a \& Figure 1b). The recirculating system consisted of aquaponic tray (PVC pipe: $\varnothing=3$ inches, length $=2.0 \mathrm{~m}$, width $=1.2 \mathrm{~m}$, vegetables pot with $\varnothing=6 \mathrm{~cm}$ as many as 36 pieces) (Figure 2); dripping system aquaponic tray (PVC pipe: $\varnothing=1 / 2 \mathrm{inch}$, length $=9 \mathrm{~m}$ and 36 pieces of vegetables pot $\varnothing=22 \mathrm{~cm}$ ); TDS meter and $\mathrm{pH}$ meter. 


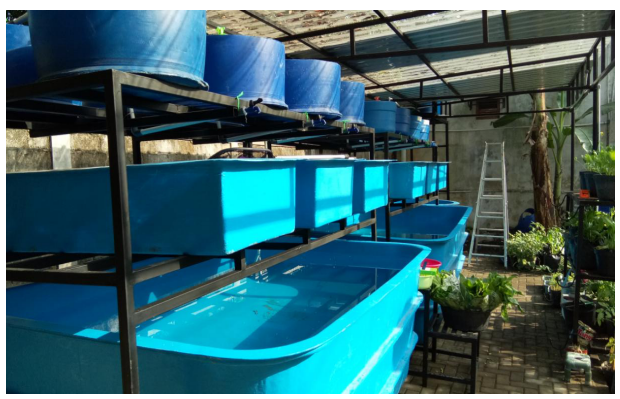

(a)

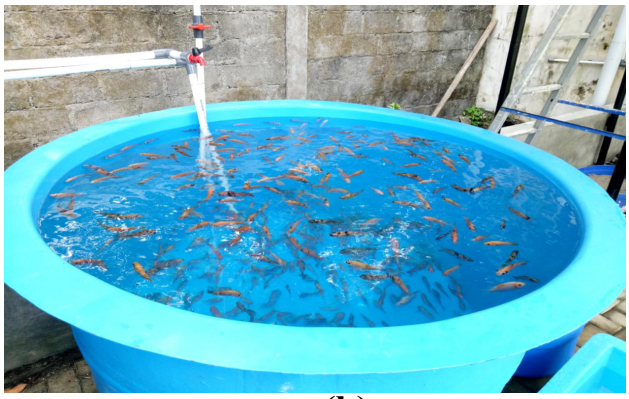

(b)

Figure 1. Rectangular fish tank (a) and cylindrical fish tank (b)

\subsection{Research procedures}

The aquaponic system was set up as follows: (a) installation of aquaponic facilities with fish and vegetable cultivation tank; (b) installation of water recirculating system (pipe, pumps and reservoirs of clean water and wastewater); installation of wastewater recirculating system for growing vegetables (pipe, dripping system, and tank); (c) installation of three-tiered shelves ; (d) filling in clean water in fish culture tanks; (e) installation of electricity system; (f) stocking the seeds of red tilapia and planting green mustard seeds in a vegetable cultivation installation; (g) fish feeding (4 times per day) and recirculation of wastewater in vegetable cultivation plants; (h) measurement of the physical-chemical water quality for 3 times: $1^{\text {st }}, 2^{\text {nd }}, 3^{\text {th }}$ month ; (i) measurement of biomass growth of green mustard by measuring the weight of each vegetable pot every week and red tilapia by measuring the weight of every 25 fish samples once a week for each fish tank.

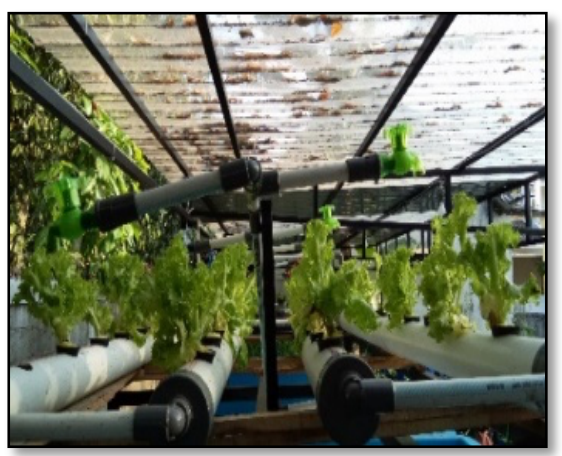

(a)

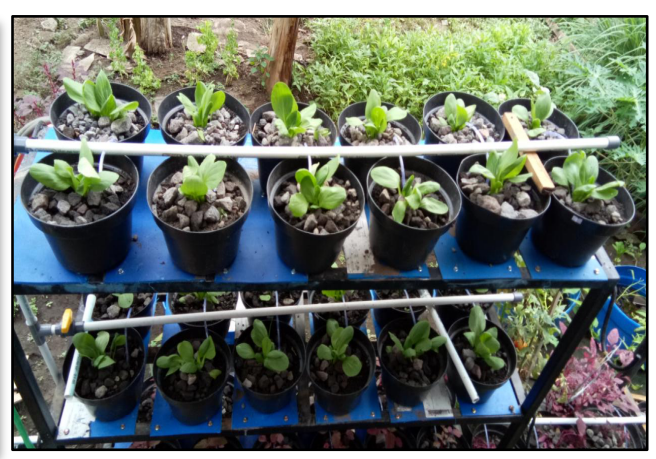

(b)

Figure 2. Aquaponic tray for recirculating system (a) and dripping system (b)

\subsection{Research methods}

Water samples for water quality analysis for red tilapia culture were taken at 2 points namely on the surface and bottom of the water using plastic bottles, then further analysis in Central Laboratory of Environmental Health Engineering and Disease Control, Yogyakarta Special Region). Measurement in the field was using a pH meter (pen type, $\mathrm{pH}$ 009-1 and TDS meter type YL-TDS2-A). Water samples were taken and analyzed 3 times during the fish 
cultivation period. Water quality of water discharge for growing vegetables was measured at the inlet to the cultivation trays for both systems by methods as described above.

Data were analysed quantitatively, qualitatively and descriptively [7]. Bioconversion parameters (growth of greens mustard and red tilapia) and bioeconomic (total selling value of vegetables and fish) in one cycle of fish culture.

\section{Results and Discussion}

Water quality for red tilapia culture and wastewater quality for growing green mustard in both recirculating and dripping systems along with wastewater discharge are shown in Table 1.

\subsection{The water quality (pH, Temperature, EC, TDS, $\mathrm{NH}_{3}, \mathrm{NO}_{2}, \mathrm{NO}_{3}$ ) in red tilapia culture tank}

Water $\mathrm{pH}$ in red tilapia tank ranged from $7.2-7.4$ with the optimal condition of $6-9$ (Table 1). The $\mathrm{pH}$ in red tilapia culture tank showed neutral condition and suitable for fish culture, but it was significantly affected by the residual feed that settled and fish metabolites that will be decomposed by microbes. Nitrifying bacteria degrade ammonia from the uneaten feed and fish feces into nitrites, then overhauled by nitrobacter bacteria to nitrate at \pm 8.5 of optimum $\mathrm{pH}$ [8]. According to [9], the $\mathrm{pH}$ value for growing tilapia ranges between $6.1-7.6$. The addition of liquid biofertilizers at different concentrations resulted in the response pattern at the same $\mathrm{pH}$ value in each test treatment, which was increased in each week of observation, but the increase was still be tolerated by fish. According to [10], the $\mathrm{pH}$ value for growing tilapia in stagnant water tank ranges from $6.5-8.5$. According to [11], the $\mathrm{pH}$ value of water suitable for the growth of tilapia is $6.0-8.5$ with a tolerance range between $5.0-11.0$.

Table 1. The water quality in red tilapia tank and wastewater for growing green mustard

\begin{tabular}{|c|c|c|c|c|c|c|c|c|}
\hline \multirow[b]{2}{*}{ No } & \multirow[b]{2}{*}{ Container } & \multicolumn{7}{|c|}{ Water \& Wastewater Quality Parameters } \\
\hline & & $\mathbf{p H}$ & $\begin{array}{l}\text { Tempe- } \\
\text { rature } \\
\left({ }^{\circ} \mathrm{C}\right)\end{array}$ & $\begin{array}{c}\mathbf{E C} \\
(\mu \mathrm{s} / \mathrm{cm})\end{array}$ & $\begin{array}{c}\text { TDS } \\
\left(\mathrm{mg} \cdot \mathrm{L}^{-1}\right)\end{array}$ & $\begin{array}{c}\mathbf{N H}_{3} \\
\left(\mathrm{mg} \cdot \mathrm{L}^{-1}\right)\end{array}$ & $\begin{array}{c}\mathbf{N O}_{2} \\
\left(\mathrm{mg} \cdot \mathrm{L}^{-1}\right)\end{array}$ & $\begin{array}{c}\mathrm{NO}_{3} \\
\left(\mathrm{mg}^{-} \mathrm{L}^{-1}\right)\end{array}$ \\
\hline \multirow[t]{2}{*}{1} & $\begin{array}{l}\text { Fish pond of red } \\
\text { tilapia }\end{array}$ & $7.2-7.4$ & $\begin{array}{c}27.4- \\
27.6\end{array}$ & $\begin{array}{c}392.0- \\
400.0\end{array}$ & $\begin{array}{c}185.3- \\
189.7\end{array}$ & $\begin{array}{c}6.147- \\
6.425 \\
\end{array}$ & $\begin{array}{c}0.605- \\
0.620\end{array}$ & $\begin{array}{c}3.751- \\
4.178\end{array}$ \\
\hline & Optimal condition & $6.0-9.0$ & $\begin{array}{l}25.0- \\
30.0\end{array}$ & $<450.0$ & $<200.0$ & $<7.00$ & $<2.00$ & $<5.00$ \\
\hline \multirow[t]{2}{*}{2} & $\begin{array}{l}\text { Recirculating system } \\
\text { for green mustard (A) }\end{array}$ & $7.0-7.5$ & $\begin{array}{c}27.6- \\
27.9\end{array}$ & $\begin{array}{c}395.5- \\
399.0\end{array}$ & $\begin{array}{c}181.2- \\
183.5 \\
\end{array}$ & $\begin{array}{c}0.002- \\
0.003\end{array}$ & $\begin{array}{l}2.631- \\
2.805 \\
\end{array}$ & $\begin{array}{c}5.200- \\
5.260\end{array}$ \\
\hline & Optimal condition & $5.0-10.0$ & $20-30$ & $<450.0$ & $<200$ & $<5.00$ & $<5.00$ & $<7.00$ \\
\hline \multirow[t]{2}{*}{3} & $\begin{array}{l}\text { Dripping system for } \\
\text { green mustard (B) }\end{array}$ & $7.1-7.6$ & $\begin{array}{l}27.8- \\
28.0\end{array}$ & $\begin{array}{c}398.7- \\
400.0\end{array}$ & $\begin{array}{c}180.5- \\
185.1\end{array}$ & $\begin{array}{l}0.002- \\
0.003\end{array}$ & $\begin{array}{c}2.810- \\
2.826\end{array}$ & $\begin{array}{c}5.205- \\
5.266\end{array}$ \\
\hline & Optimal condition & $5.0-10.0$ & $\begin{array}{c}20.0- \\
30.0\end{array}$ & $<450.0$ & $<200$ & $<5.00$ & $<5.00$ & $<7.00$ \\
\hline
\end{tabular}

Water temperature in red tilapia tank ranged from $27.4-27.6^{\circ} \mathrm{C}$ with the optimal conditions between $20-30^{\circ} \mathrm{C}$ (Table 1). Tilapia grows normally at a temperature range of $14-38^{\circ} \mathrm{C}$ and spawn naturally at temperatures of $22-37^{\circ} \mathrm{C}$. The optimal temperature for the growth of red tilapia is between $25-30^{\circ} \mathrm{C}$ [12]. This condition showed that the water temperatures were in optimal conditions. Sunlight and ambient temperature of water, other than nutrients, are limiting factors for the growth of biota and aquatic plants. The optimal environmental temperature stimulates the growth of biota and aquatic plants optimally. The 
growth rate of biota and aquatic plants occurs optimally when the water temperature at an optimum range. When the temperature of the water body changes from the minimum to the optimum condition, the growth of biota and aquatic plants increases dramatically at the highest limit [13]. Red tilapia grows normally at a temperature range of $14-38^{\circ} \mathrm{C}$ and spawn naturally at temperatures of $22-37^{\circ} \mathrm{C}$. The optimum temperature for growth and development is $25-30^{\circ} \mathrm{C}$. The growth of tilapia decreases at water temperature lower than $14^{\circ} \mathrm{C}$ and or higher than $38^{\circ} \mathrm{C}$. Fish mortality begins to occur at a temperature lower than $6^{\circ} \mathrm{C}$ and or higher than $42^{\circ} \mathrm{C}$ [15]. According to [9], the temperature range for red tilapia growth are between $24-33^{\circ} \mathrm{C}$, where in the morning the water temperature ranges from $24-26^{\circ} \mathrm{C}$, during the day $28-33^{\circ} \mathrm{C}$ and the afternoon $27-33^{\circ} \mathrm{C}$. The temperature range for tilapia culture in stagnant water is $25-32^{\circ} \mathrm{C}$ [10] and according to [11], the optimal temperature for tilapia growth is $24-33^{\circ} \mathrm{C}$, where the lowest temperature occurs in the morning and the highest temperature at afternoon and evening.

The average Electrical Conductivity (EC) value of water in a fish tank and water for growing vegetables were relatively similar, ranging from $392.0-400.0 \mu \mathrm{s} / \mathrm{cm}$ with the optimal values less than $450.0 \mu \mathrm{s} / \mathrm{cm}$ (Table 1 ). The EC of water is significantly affects the absorption of nutrients by microalgae. This will cause changes in the opening of the stomata and the growth of leaf area as for photosynthetic efficiency. In aquaponic system cultivation, nutrient concentrations available in water are influenced by species, speed of growth and density of fish; frequency of feeding and composition of feed and the rate of nitrite decomposing bacteria [8]. The quality of nutrients in culture fish flesh can be controlled based on EC values and $\mathrm{pH}$. The higher nutrient content in water, more salt content is found in the water, result the higher EC value. Increase in nutrient concentration in water is influenced by total salt content and accumulation of ions in water bodies. EC in water bodies affects plant metabolism, especially the photosynthesis rate and enzyme activity.

The ranges of TDS content in red tilapia tank culture were $185.3-189.7 \mathrm{mg}$. $\mathrm{L}^{-1}$ with the optimal condition less than $200.0 \mathrm{mg} . \mathrm{L}^{-1}$ (Tabel 1). TDS is an indicator of the number of particles or solids (organic and inorganic compounds) in the form of calcium, magnesium, potassium, carbonate, nitrate, bicarbonate, chloride and sulfate salts with particle sizes smaller than 1.0 nanometer [14]. TDS levels in black tilapia culture range from $182.20-$ $187.55 \mathrm{mg} . \mathrm{L}^{-1}$, and grow out pond of the fish range $190.12-192.05 \mathrm{mg} . \mathrm{L}^{-1}$ [15]. [16] stated that the maximum adaptable TDS level for the growth of cultured fish is $200.0 \mathrm{mg}$. $\mathrm{L}^{-1}$. The lower TDS value in water give the higher growth rate of fish. TDS has a direct effect on water turbidity and suspended solids. Suspended solids interfere with fish life and block the entry of sunlight for photosynthesis of phytoplankton. Turbidity of water is one of the important parameters of the water quality in aquaculture. The suspended material is usually dominated by detritus. It can be used as an indicator of water pollution and has a significant effect on (a) disruption of aquatic biota's respiration and vision ability (b) reduce dissolved oxygen levels in water and (c) inhibits the penetration of light into the water.

The $\mathrm{NH}_{3}$ concentration in the red tilapia tank water ranged from $6.147-6.425 \mathrm{mg}$. $\mathrm{L}^{-1}$ with the optimal condition less than $7.00 \mathrm{mg} . \mathrm{L}^{-1}$ (Table 1). High Ammonia levels in water are important indicators of the water nutrient content that lead to eutrophication followed by low dissolved oxygen levels, increased BOD, TSS and the risk outbreak of fish diseases, especially by fungi and bacteria. Increase in high levels of ammonia and nitrite are toxic and cause mass mortality of fish. Ammonia and nitrite levels in water for fish culture must be tightly controlled through a continuous aeration process to create aerobic conditions in water to accelerate the growth of nitrobacter that responsible for the breakdown of nitrite into nitrates known as non-toxic compounds in aquatic biota, and nitrifying bacteria which accelerates the decomposition of ammonia and nitrite compounds into nitrates to be used as aquatic plant nutrients [17]. Ammonia levels are still in the tolerance range, which were 0.002 $-0.017 \mathrm{mg} . \mathrm{L}^{-1}$ until on the $14^{\text {th }}$ day of fish culture [9]. Ammonia value increased 
continuously until the $28^{\text {th }}$ day which reached higher levels than the tolerable range $(<0.02$ mg. $\left.\mathrm{L}^{-1}\right)$ as recommended by [10]. Although, ammonia value was higher than the tolerable limit [10], tilapia survival rates were high (75 - 85\%). Organic and inorganic materials in fish rearing mainly come from unconsumed feed and fish metabolism. The accumulation of organic and inorganic materials causes the formation of compounds that are toxic to fish. The nitrification process is needed to convert ammonia into harmless nitrate through nitrite compounds as intermediates [18]. According to BSN, the level of ammonia in grow out pond of tilapia in calm water ponds is $<0.02 \mathrm{mg} . \mathrm{L}^{-1}$. Feed consumption and growth of tilapia decrease at an ammonia concentration more than $0.08 \mathrm{mg} . \mathrm{L}^{-1}$. The ammonia concentration at $0.08 \mathrm{mg} . \mathrm{L}^{-1}$ lower the immune system of tilapia.

Nitrite content in water of the red tilapia tank ranged from $0.605-0.620 \mathrm{mg} . \mathrm{L}^{-1}$ (Table 1) with the optimal levels less than $2.00 \mathrm{mg} . \mathrm{L}^{-1}$. Low $\mathrm{NO}_{2}$ concentrations indicates that in the red tilapia culture tank, optimal $\mathrm{NO}_{2}$ decomposition occurred by nitrobacter which is supported by the availability of oxygen in sufficient concentration. Conversely, high levels of $\mathrm{NO}_{2}$ in green mustard cultivation containers might be due to accumulation process. The growth of nitrifying bacteria which are responsible for decomposition of ammonia into nitrites (toxic compounds for cultivation biota), and nitrobacter bacteria which accelerate $\mathrm{NO}_{2}$ decomposition to $\mathrm{NO}_{3}$ are crucial in this system [15]. Nitrogen comes from organic waste in various forms ( $\mathrm{N}$-organic, $\mathrm{N}$-ammonia, $\mathrm{N}$-nitrite and $\mathrm{N}$-nitrate). In industrial wastewater, the organic $\mathrm{N}$ content is relatively higher than $\mathrm{N}$-ammonia, whereas in wastewater at warm temperatures, the $\mathrm{N}$-organic content is relatively lower than $\mathrm{N}$-ammonia. Nitrite and nitrate in wastewater are at very low concentrations [19]. The forms of nitrogen undergo transformation as part of the nitrogen cycle, namely: (a) $\mathrm{N}$-inorganic assimilation $\left(\mathrm{NH}_{3}\right.$ and $\mathrm{NO}_{3}$ ) by plants and autotrophic bacteria to form organic nitrogen (amino acids and proteins); (b) the oxidation of $\mathrm{NH}_{3}$ to $\mathrm{NO}_{2}$ and $\mathrm{NO}_{3}$ by aerobic bacteria took place optimally at $\mathrm{pH} 8$ under conditions of water body temperature $\pm 30^{\circ} \mathrm{C}$; (c) ammonification of $\mathrm{N}$-organic to produce $\mathrm{NH}_{3}$ during the decomposition process of organic matter, mostly carried out by microbes and fungi; (d) the reduction of nitrate into nitrite, nitrous oxide $\left(\mathrm{N}_{2} \mathrm{O}\right)$ and nitrogen $\left(\mathrm{N}_{2}\right)$ molecules takes place optimally under anoxic conditions involving bacteria and fungi.

Nitrate levels in red tilapia culture tank ranged from $3.751-4.178 \mathrm{mg} . \mathrm{L}^{-1}$ (Table 1), with the optimal condition less than $5.00 \mathrm{mg} . \mathrm{L}^{-1}$. The levels were significantly lower than the water nitrate levels in the recirculation and dripping system systems in for growing vegetables. This condition showed that the activity of nitrobacter to decompose nitrite into nitrate was higher in the fish culture tank as the appropriate temperature and $\mathrm{pH}$ and dissolved oxygen levels. The higher $\mathrm{pH}$ of water causes the higher ammonia toxicity because most of it is in the form of $\mathrm{NH}_{3}$ that is more toxic than in ionic form $\left(\mathrm{NH}_{4}^{+}\right)$[20]. According to [16], the ammonia in fish pond water comes from fish feed and fish feces. The amount of ammonia produced might be estimated from the use of net protein (added protein) from the feed given. According to [18], chemical compounds of ammonia nitrogen ( $\mathrm{N}$-ammonia) in water from feed and fish feces provide growth stimulation in aquatic plants. The concentration of organic and inorganic nitrogen compounds in the water will change as the changes of environmental conditions that might be problematic for fish culture. According to [20], the concentration of organic nitrogen in water bodies varies greatly, depending on fish cultivation technology. Ammonia nitrogen $\left(\mathrm{NH}_{3}-\mathrm{N}\right)$ concentrations are quite high in ponds that are given fertilizer rather than only feed. Nitrogen also contains dissolved organic matter $\pm 1.0 \mathrm{mg} . \mathrm{L}^{-1}$ in unpolluted waters, while in waters with its high level $\left(2-3 \mathrm{mg} \cdot \mathrm{L}^{-1}\right)$ causes phytoplankton blooms. 


\subsection{Water quality ( $\mathrm{pH}$, Temperature, EC, TDS, $\mathrm{NH}_{3}, \mathrm{NO}_{2}, \mathrm{NO}_{3}$ ) of wastewater in recirculating and dripping systems}

The value of $\mathrm{pH}$ in wastewater of green mustard cultivation with recirculating and dripping systems ranged from 7.0 - 7.6 with the optimal condition among 5.0 - 10.0 (Table 1). The $\mathrm{pH}$ conditions in the three cultivation containers are relatively the same. It is shown that the $\mathrm{pH}$ value of fish aquatic bodies and wastewater for vegetable cultivation are neutral. Optimal nutrient absorption by several plant species occurs at $\mathrm{pH} 6.0$ [8] [21]. The range of $\mathrm{pH}$ values in aquaponic system must be strictly controlled in order to achieve optimal conditions to support the life and activity of nitrifying bacteria and cultivated vegetable growth. High acidity reduces the efficiency of essential macro nutrient absorption by plant roots which are very limited in aquaponic systems. The degree of acidity affects the growth and survival of aquaponic/hydroponic plants. Plants need nutrient solution with a neutral $\mathrm{pH}(6.0-7.5)$ to grow and produce well and can survive long, can be absorbed optimally by plant roots. Micro nutrients such as $\mathrm{Mn}, \mathrm{Zn}$, and Fe will be chemically bound in alkaline environment, so that it cannot be absorbed optimally by plant roots, and as a result the plants experience nutrient deficiencies and stunted growth.

The temperature of the wastewater for green mustard cultivation with recirculating and sugar cane systems ranged from $27.6-28.0^{\circ} \mathrm{C}$ with the optimal condition among $20.0-$ $30.0^{\circ} \mathrm{C}$, (Table 1). This condition shows that the temperature of the water in both aquaculture and vegetable cultivation were in optimal conditions. Sunlight and ambient temperature of water bodies are limiting factors in the growth of aquatic plants, where the optimal environmental temperature will stimulate the growth of aquatic plants optimally. The growth rate of aquatic plants can take place at maximum speeds when the temperature conditions of the water body reach optimum because other environmental factors become neutral [13]. The optimum temperature range for accelerating the photosynthetic process of aquatic plants ranges from $10-30^{\circ} \mathrm{C}$. According to [22], if the ambient temperature is higher and or lower than the optimum temperature conditions, the photosynthesis rate is reduced.

TDS content in the vegetable cultivation with in both recirculating and dripping system are $180.5 \mathrm{mg} . \mathrm{L}^{-1}$ and $185.1 \mathrm{mg} . \mathrm{L}^{-1}$ with the optimal condition less than $200.0 \mathrm{mg}$.L $\mathrm{L}^{-1}$ (Tabel 1). TDS is an indicator of the number of particles or solids in the form of organic and inorganic compounds in the form of calcium, magnesium, potassium, carbonate, nitrate, bicarbonate, chloride and sulfate salts of sizes smaller than 1.0 nanometer [14]. Suspended solids interfere with fish life and block the entry of sunlight for photosynthesis of aquatic plants. The dominant suspended material is formed from detritus, so at certain limits it can be used as an indicator of water body pollution and has a significant effect on turbidity, reduce oxygen levels dissolved in water bodies and inhibits the penetration of light into the body of water [24].

Based on the Table 1, it can be seen that the ammonia $\left(\mathrm{NH}_{3}\right)$ content in the vegetable cultivation with recirculating and dripping system are of $0.002-0.003 \mathrm{mg} . \mathrm{L}^{-1}$, with the optimal condition less than $5.000 \mathrm{mg} . \mathrm{L}^{-1}$. The difference in ammonia levels is caused by differences in the number, activity and capacity of anaerobic bacteria and aerobic bacteria, and mechanical processes. The amount of feed given by 4 to 5 times a day is a major factor in increasing the ammonia content of water bodies, compared with ammonia levels in vegetable cultivation containers. Low ammonia levels in vegetable cultivation containers are caused by two main factors, namely: the speed of decomposition of ammonia and nitrite by nitrifying bacteria in waste water reservoirs and speed of absorption by plant/vegetable roots [17]. Ammonia levels that are high enough in aquaculture bodies are important indicators of the nutrient content of water bodies that lead to e eutrophication followed by low dissolved oxygen levels, increased BOD, TSS and fish pests and diseases. This condition shows that if the accumulation of nutrients in fishponds is not followed by draining or suctioning and/or used every day as a source of nutrition for vegetable cultivation with aquaponics system, it 
will certainly reduce the quality of the water body to the lowest limit affecting fish life [17, 19].

Based on the Table 1, it can be seen that nitrite $\left(\mathrm{NO}_{2}\right)$ content in the vegetable cultivation with recirculating and dripping system are of $2.731-2.826 \mathrm{mg} . \mathrm{L}^{-1}$, with the optimal condition less than $5.000 \mathrm{mg} \cdot \mathrm{L}^{-1}$. Conversely, high levels of $\mathrm{NO}_{2}$ in green mustard cultivation containers due to accumulation symptoms. As friendly as ammonia, nitrite levels in fish pond water bodies must be tightly controlled through conditioning suitable for accelerating the growth of nitrifying bacteria which are responsible for decomposition of ammonia into nitrites (toxic compounds for cultivation biota) and nitrobacter bacteria which accelerate $\mathrm{NO}_{2}$ decomposition to $\mathrm{NO}_{3}$ [19]. Nitrogen is sourced from organic waste in various forms (Norganic, $\mathrm{N}$-ammonia, $\mathrm{N}$-nitrite and $\mathrm{N}$-nitrate). In industrial wastewater, the $\mathrm{N}$-organic content is relatively higher than $\mathrm{N}$-ammonia, whereas in wastewater with warm temperatures, the Norganic content is relatively lower than $\mathrm{N}$-ammonia. Nitrite and nitrate in wastewater are at very low concentrations [19]. The forms of nitrogen undergo transformation as part of the nitrogen cycle, namely: $\mathrm{N}$-inorganic assimilation $\left(\mathrm{NH}_{3}\right.$ and $\left.\mathrm{NO}_{3}\right)$ by plants and autotrophic bacteria to form organic nitrogen (amino acids and proteins); the oxidation of $\mathrm{NH}_{3}$ to $\mathrm{NO}_{2}$ and $\mathrm{NO}_{3}$ by aerobic bacteria took place optimally at $\mathrm{pH} 8$ under conditions of water body temperature $\pm 30^{\circ} \mathrm{C}$; ammonification of $\mathrm{N}$-organic to produce $\mathrm{NH}_{3}$ during the decomposition process of organic matter, mostly carried out by microbes and fungi and the reduction of nitrate into nitrite, nitrous oxide and nitrogen molecules takes place optimally under anoxic conditions involving bacteria and fungi [24].

Based on Table 1, it can be seen that nitrate levels in the vegetable cultivation with recirculating and dripping system among $5.200-5.266 \mathrm{mg} . \mathrm{L}^{-1}$, with the optimal condition less than $7.000 \mathrm{mg} . \mathrm{L}^{-1}$. This condition shows that the activity of nitrobacter bacteria in the decomposition of nitrite into nitrate is higher in the reservoir of red fish aquaculture because it is supported by conditions of temperature and $\mathrm{pH}$ and the availability of oxygen. According to [18], chemical compounds of ammonia nitrogen ( $\mathrm{N}$-ammonia) in water bodies sourced from feeds and fish feces provide growth stimulation in aquatic plants. The concentration of organic and inorganic nitrogen compounds in the waters, will change if supported by environmental conditions so that it will cause new problems in water bodies. According to [20], the concentration of organic nitrogen in water bodies varies greatly, depending on fish cultivation technology. Ammonia nitrogen concentrations are quite high in ponds that are given fertilizer rather than only given by feed.

\subsection{Wastewater Discharge, bioconversion and bioeconomics of green mustard cultivation}

\subsubsection{Wastewater discharge for the cultivation of green mustard}

The total water discharge used in the vegetable cultivation tray with a recirculation system was 160.0 liters per day \& in the molasses system was 137.5 liters per day. Release of wastewater in the cultivation trays is only carried out for 5 times (at 06.00, 10.00, 14.00, $16.00 \& 18.00$ ) every day. The use of water for aquaponics vegetable cultivation is more than the conventional method (only 2 times every day: morning and evening) with a limited amount of water, without using calculations.

Important constraints in aquaponics system cultivation that must be done are: (a) reducing the total suspended solids in water supply from fish tank that can close the piping in the drip-sugar cane system and plant roots; (b) designing wastewater storage tanks that have special columns at the base to precipitate suspended particles so that they are not included in the drainage/recirculation channel to vegetable cultivation units; (c) recirculating wastewater in a vegetable cultivation tank must be carried out in a relatively long time and 
repeatedly before being returned into the fish tank so that the nutrients can be absorbed maximally by the roots of vegetables and (d) maximizing the use of nutrient-rich aquaculture wastes for the development of cultivation of various economically important vegetables and fruits in both vertical and horizontal systems.

\subsubsection{Bioconversion and bioeconomic analysis in aquaponic system cultivation}

Bioconversion analysis is calculating the total growth of vegetable biomass (leaves, stems and roots) based on the use of volume (discharge) of channeled wastewater. Bioeconomic Analysis is to calculate the total market value (selling value) of the total vegetables produced per culture system as well as the total fish produced per harvest season (Table 2). Based on the analysis of bioconversion, it is known that the total growth of green mustard biomass with recirculating system cultivation $=92.50 \mathrm{~kg} / \mathrm{unit}$ and the dripping system $=138.00 \mathrm{~kg} / \mathrm{unit}$ (ratio 1.0: 1.5) with total production $=230.50 \mathrm{~kg} /$ unit and production of red tilapia $=48.00$ $\mathrm{kg}$. The results of the bioeconomic analysis show that the selling value of green mustard production of IDR 8,643,750.00 and red tilapia is IDR. 1,680,000.00 (Total, IDR. $10,323,750.00)$. Based on the results of these calculations, it appears that the cultivation of vegetables with dripping system is more productive than the recirculating system.

The cultivation of aquaponics systems is a smart cultivation model in an effort to increase the income of groups of fish and vegetable farmers, by utilizing narrow and vertical land without using large amounts of water and space, which only needs very limited land (12 $\mathrm{m} \mathrm{x}$ $4 \mathrm{~m}=45 \mathrm{~m}^{2}$ ). Aquaponics system cultivation is very suitable to be developed in marginal lands with limited groundwater, but has high economic potential to improve the economic status of the weak economic community groups. On the other hand, fish and vegetables produced have large market potential with prices that are quite competitive in traditional markets and modern markets so as to provide economic improvements to the group of farmers.

Table 2. Bioconversion and bioeconomics analysis of fish and vegetables in aquaponic systems

\begin{tabular}{|c|c|c|c|c|c|c|c|}
\hline \multirow[b]{2}{*}{ No } & \multirow[b]{2}{*}{ Types of Products } & \multirow{2}{*}{\begin{tabular}{|c} 
Initial \\
Weight of \\
Seed (gr)
\end{tabular}} & \multicolumn{2}{|c|}{ Harvest (per season) } & \multirow{2}{*}{$\begin{array}{l}\text { Selling } \\
\text { Price } \\
\text { (IDR/kg) }\end{array}$} & \multirow[b]{2}{*}{$\begin{array}{l}\text { Aarvested } \\
\text { Period }\end{array}$} & \multirow{2}{*}{$\begin{array}{l}\text { Amounth } \\
\text { (IDR) }\end{array}$} \\
\hline & & & $\begin{array}{c}\text { Total } \\
\text { length }(\mathrm{cm})\end{array}$ & \begin{tabular}{|c|} 
Total \\
weight $(\mathrm{kg})$
\end{tabular} & & & \\
\hline & $(1)$ & $(2)$ & (3) & (4) & $(5)$ & $(6)$ & $(7)=(4) \times(5) \times(6)$ \\
\hline 1 & $\begin{array}{l}\text { Production of } \\
\text { green mustard }\end{array}$ & & & & & & \\
\hline & $\begin{array}{ll}\text { a. } & \text { Recirculating } \\
\text { system }\end{array}$ & $4.5-6.5$ & $30.0-35.0$ & 92.50 & 7,500 & 1 & $693,750.00$ \\
\hline & b. Dripping system & $4.5-6.5$ & $35.0-42.0$ & 138.00 & 7,500 & 1 & $1,035,000.00$ \\
\hline & Sub total & - & - & 230.50 & 7,500 & 5 & $8,643,750.00$ \\
\hline & $\begin{array}{ll}\text { c. } & \text { Ratio of } \\
\text { biomass }(\mathbf{A} / \mathbf{B})\end{array}$ & - & - & $1.0: 1.5$ & - & - & - \\
\hline 2 & $\begin{array}{l}\text { Production of Red } \\
\text { Tilapia }\end{array}$ & $8-10$ & $11-22$ & 48.00 & 35,000 & 1 & $1,680,000.00$ \\
\hline & Sub total & - & - & - & - & - & $1,680,000.00$ \\
\hline & Total & - & - & - & - & - & $10,323,750.00$ \\
\hline 3 & $\begin{array}{l}\text { Economic Ratio of } \\
\text { Green Mustard } \\
\text { and Red Tilapia }\end{array}$ & - & - & - & - & - & $5.14: 1.00$ \\
\hline
\end{tabular}

Notes: $\mathrm{A}=$ cultivation of green mustard vegetables in recirculating system 
$\mathrm{B}=$ cultivation of green mustard vegetables with dripping system

\subsubsection{The advantages of aquaponics system aquaculture}

The aquaponics system cultivation business is referred to as "alternative solutions for converting environmental problems into economic sources of society", with the following advantages: (a) utilizing land and water resources maximally through vertical vegetable cultivation (saving space) and reusing wastewater from fish farming as a manifestation of groundwater conservation and rehabilitation efforts ; (b) the technology of aquaponics system cultivation is very easy to implement with relatively low operational costs and high output ; (c) the aquaponic system cultivation business greatly saves labor use because the operational system is easy to operate, can be operated by 1 and or 2 people per business unit (classified as a very economical business) and (d) vegetable cultivation in aquaponic aquaculture systems can be harvested in a relatively short time (around 25 days) so that it has a greater economic value than fish cultivation (the main product) [23]. The business of cultivating aquaponic systems (green mustard and red tilapia) using recirculating and dripping system, turned out to have an economic value ratio for vegetables that was larger than red tilapia (reaching $5.14: 1.0)[24][20]$.

\section{Conclusions and Recommendations}

\subsection{Conclusions}

The physical-chemical quality of red tilapia aquaculture pond water still meets the water quality requirements for the cultivation of green mustard vegetables even though the $\mathrm{pH}$ value and total dissolved solids are close to the highest limit. The discharge of wastewater from the red tilapia aquaculture business for vegetable green mustard cultivation reached 5.2 $-6.6 \mathrm{~L} /$ minute, apparently able to provide a significant influence on the growth of vegetable biomass $(230.00 \mathrm{~kg})$ in the recirculating and dripping system in 5 (five) times of harvest and production of red tilapia of $48 \mathrm{~kg}$. The total economic value of the production of red tilapia and mustard greens in one cultivation cycle reaches IDR 10,323,750.00.

\subsection{Recommendations}

The use of red tilapia aquaculture water for vegetable cultivation businesses should be given a sufficient waiting time (about 1 day) before use, in order to convert ammonia and nitrite to nitrate, while reducing the $\mathrm{pH}$ of wastewater close to neutral conditions $(\mathrm{pH}<7,5)$. The discharge of aquaculture wastewater is large enough so that it must be utilized optimally for the development of a variety of important economic and fruit cultivation businesses on a larger scale.

\section{Acknowledgments}

There are countless thanks and awards conveyed to the honorable: Director of Research and Community Service, Kemristekdikti Jakarta, Chairperson of UGM LPPM and Dean of the Faculty of Agriculture UGM who have given us approval and trust to carry out this research for 3 fiscal years $(2017,2018,2019)$ 


\section{References}

1. Anonimous 2015. Presidential Regulation of the Republic of Indonesia, Number 2, 2015 concerning National Medium Term Development Plan (RPJMN), Indonesia (2015)

2. L. Sahubawa, B. Triyatmo and E. Ambarwati. Bioconversion and Bioeconomics of Red Tilapia Acuaculture Wastewater as a Source of Nutrient (Nitrate) to the Growth of Red Spinach Biomass in Aquafonic System Cultivation by Recirculation Method. Paper presented at the Indonesian National Biotechnology Workshop. Biotechnology Study Program, Postgraduate School, Gadjah Mada University Yogyakarta, October 27, 2018 (2018a)

3. Junus and L. Sahubawa. Design of Tray for Cultivating Environmentally Friendly Aquaponic Fish Systems. Summary of Results of Discussion of UGM Akuaponik Research Team with Partners (KUB Mina Abadhi Farm Yogyakarta), Yogyakarta (unpublished) (2017)

4. I. Sy. Roidah. Land Use by Using Hydroponic Systems. Jour. of Tulungagung University, Bonorowo, 1 (2): 43-50 (2014)

5. L. Sahubawa, B. Triyatmo and E. Ambarwati.Economic and Institutional Strengthening of Aquaculture Micro-Small Scale Aquafonics Systems. Paper Presented at the National Seminar on Marine and Fisheries Socio-Economics. The Center for Marine and Fisheries Socio-Economic Research (BBRSEKP) collaborates with the Indonesian Marine and Fisheries Socio-Economics Research Network (IMFISERN) and the Conservation Strategy Fund (CSF) Indonesia. Mina Bahari IV Building, Ministry of Maritime Affairs and Fisheries, Jakrta, Batu Street No. 1, Gambir - Jakarta, September 24, 2018 (2018b)

6. Wagiman. Practical Module for Industrial Waste Control. Study Program of Strata I. Department of Agricultural Industrial Technology. Faculty of Agriculture Technology, Gadjah Mada University, Yogyakarta (2014)

7. Sugiyono. Descriptive Research Method. A Comprehensive Approach in Conducting Field Research. Published by Airlangga Surabaya (2010)

8. https://www.dunia-perairan.com/2019/05/fisika-air-dan-pengaruhnya-terhadap.html, accessed 23-07-2019, at 14.00)

9. K. Tyen, Panggabean, Ade Dwi, Sasanti and Yulisman. Water Quality, Survival Rate, Growth and Feed Efficiency of Tilapia With Biofertilizer Liquid in Water Media Rearing, Jour. of Indonesia Swamp Aquaculture, 4(1) :67-79 (2016) ISSN : 2303-2960 (2016)

10. BSN. SNI No.7550:2009, Production of Tilapia (Oreochromis niloticus Bleeker) Enlargement Class in Calm Ponds, National Standardization Agency, Jakarta (2009)

11. K. Kordi. Acaculture. Citra Aditya Bakti Press, Bandung (2009)

12. https://duniapertanian101.blogspot.com/2015/10/paruh-pH-larutan-nutrisi-pada.html, accessed: 07-23-2019, at. 01.03

13. Khairuman and Amri. Introduction to Morphology and Anatomy of Fish Reproduction. Practical Material of Reproduction Physiology in Aquatic Animals. Department of Aquaculture, Faculty of Agriculture, University of Lampung (2007)

14. https://citra1401.blogspot.com/2011/04/paruh-faktor-fisika-dalam-budidaya.html, accessed 23-07-2019, at 14.30 
15. H. Khairudin and K. Amri. Red Tilapia Aquaculture. Agri Media Pustaka Press. ISBN 979-006-456-X, 108 pages (2013)

16. Kordi and Andi. Water Quality Parameters for Fish Cultivation. Fisheries Extension, Fish Cultivation, Fish Processing and Ornamental Fish. Textbook, Publisher PT. Penebar Swadaya Nelayan Abadi, Jakarta (2009)

17. A. Siregar. Content and Impact of Ammonia, Nitrite and Nitrate in Industrial Wastewater. (on line). (http://www.blogspot.com, accessed 11-19-2018, at 10:40 (2005)

18. K. Wijaya. Effects of Giving Nitrification Microbial Consortium to Ammonia Concentration in Pond Water. Journ. of Environmental Engineeringal, P3TL-BPPT, 4(2):62-67 (2003)

19. Prasatya. Feasibility Analysis and Optimization of Cultivation of Green Mustard and Hydroponic Vegetable Cultivation with the NFT System (Nutrient Film Technique) at PT. Joy Farm, Depok. Final Project, Faculty of Agricultural Technology, Bogor Agricultural University (2009)

20. W. Sari, Y. Kitty and A. Dwiranti. Hydroponic System with the Nutrient Film Technique (NFT) and Wick on Planting Green Mustards. Surya Octagon Interdisciplinary Jour. of Technology, 1(2):223-225, ISSN: 2460-8777 (2016)

21. Pantella, Rakocy, Rosta and Hamidpour Crop Physiological Response to Nutrient Solution for Electrical Conductivity and $\mathrm{pH}$ in an Ebb-and-Flow Hydroponic System. Inter. Jour. of Scientia Horticultura, 194(1): 34-42. Copyright (C) 2015 Elsevier B.V. All rights reserved (2012)

22. httpmedia.unpad.ac.idthesis2301102009230110090127_2 6074.pdf, accessed on July 22, 2019, at 10:15 WIB

23. R. Domingues, A. B. Barbosa and H. Galfawo. Ecological Indicators, 24, 245-255, http://dx.doi.org/10.1016/j.ecolind.2012.06.020 Brito, Ana C. Ecological Indicators, Volume 27 - Apr 1, 2013 (2012)

24. F. F. Nur, H. Sirajuddin, Abdullah, and P. Asih. Analysis of Water Quality in the Aquaponic Irrigation System. Scientific Jour. of Agricultural Engineering and Biosystems, 5(2):385-394 (2017) 